\title{
Online Interactive Communication via Academic Blogging Activities Among Indonesian EFL Students
}

\author{
Shella Shafira Lubis ${ }^{1}$ and Budianto Hamuddin ${ }^{2}$ \\ ${ }^{1,2}$ Universitas Lancang Kuning, Pekanbaru. Indonesia \\ shella.sl@unilak.ac.id
}

\begin{abstract}
ARTICLE HISTORY
Received : 2019-08-18

Revised : 2019-08-25

Accepted : 2019-08-31
\end{abstract}

\section{KEYWORDS}

Discussion

Online interaction communication

Knowledge construction

Language function

Pragmatics

\begin{abstract}
Indonesian people in the conversation using English in many ways, such as face to face and social media. The purpose of this research is to identify students' online interactive communication in their blog's comment. It focuses among students as Indonesian EFL students in Morphology class in Universitas Lancang Kuning (Unilak). This study also eager to know what type of language function and phase of knowledge construction on students blogging activities on selected IT platform classroom, i.e. Morphology course. The method employ in this research is a qualitative descriptive method. This study did take the comments' blog of all students in Morphology class. Then This study analyzed those comments. The result of this research, students, showing some dominant type in Knowledge Construction, i.e., Sharing and Comparing of opinion in Blog The present study also reveals the use of Expressing and Supporting Opinions as the dominant types in Language.
\end{abstract}

\section{Introduction}

As the world keeps moving and globalization occurs, the English language plays an essential role in many sectors, especially in communication (Chopra, 2015). Indonesian people start a conversation using English in many ways, such as face to face and using social media. English began to become a universal language in Indonesian netters. Therefore, everyone cannot deny the importance of English has been shown presently.

Social media helps us to have online interactive communication. Online interactive communication is simultaneous or 'real-time' exchange of information over a transmission medium, such as during a telephone conversation, video conferencing, or internet relay chat sessions. Indonesian people always use media online or social media to communicate with other people such as in Facebook, WhatsApp, Blackberry Messenger, LINE, blog and other. They can share their opinion, suggestion, asking the question, and even bullying in one forum. Moreover, the touch of Information Technology (IT) such as blog also has been used as a tool and alternative learning area in the media of English language teaching.

It is already common to have a blog as language teaching. The blog is a media which lecturer use in developing students' skill in English subject. It is a simple media used by many writers in the world. This research would show to the reader, lecturer, and this study in Faculty Teachers Training and Education,
Universitas Lancang Kuning about students' online interactive communication in their blog's comment. The students are expected to be able to write online interactive communication in their blog's comments based on what is asked, such as language function and phase of knowledge contraction. Students' online interactive communication in students' blog is important to be an evaluation for lecturer and students about how good their communication in the blog using English. Most students are still enjoying their activity in communication using the blog. This phenomenon supports this study to take research.

In these few years, blogs have been used for teaching the purpose and gain a lot of popularity. Generally known as a blog, can be defined as an online diary which allows people to publish their experiences, thoughts, videos, pictures, and other on the internet for other people to read or see (Wang, Fix, \& Bock, 2005). The blog has been used as a tool and alternative learning area in the media of English language teaching. A blog offers various advantages to simplify students and lecturers process of learning in an effective way by accessing all kind of information and possibility to have a learning process in anywhere, anytime and with anyone.

The effectiveness of blog's application in English language teaching (henceforth: ELT) situation has been discussed and recommended in many previous this study since it has proven can improve the skill, motivation, and the willingness to learn English. It also even gives maximum benefit to the teachers, lecturers 
of English, or the students of the English department in many educational institutions. Noytim's research, 2010; Butler, 2011 also Aydan, 2014, were some studies showing and recommending the blog as one of the most suitable media for teaching English. Since 2015, the used of students' blog initiated as an alternative teaching medium in some courses at English Education Program (PBIG) at Dept. of English language Education, Faculty of Teacher Training and Education (FKIP) in Universitas Lancang Kuning such as Reading, Writing, Introduction to Linguistics, Semantics, Error Analysis, and Discourse Analysis. The escalation trend of blog owner or blogger, as well as the posts, increasing significantly, 208 active bloggers are listed as the students of PBIG FKIP Unilak who use the students' blog as teaching and learning tool (Hamuddin, 2016).

The data shows us that blog is not only functioned as a personal journal on the virtual world with lexical, phrase, sentences, punctuation, symbol even pictures, but also as an alternative learning, where blog is chosen as one of the ways to post assignments such as article review, slideshow, and even the multimedia material, and or to be used as a tool to improve the skill in English especially writing (Hamuddin, 2016, p.4). Moreover, the article post is the perfect area to train the ability of writing by posting a different kind of post in English, whether academically or non-academically. The feedback in the comment section at the bottom of each article is also an option of "the perfect area" to train their ability in writing, but also this can be "an interesting place" with the whole of its content such as comments, questions, critics, and even some statements.

Furthermore the students are expected to be able to do online interactive communication in their blog's comment that include language function such as compare and contrast, persuasion, asking question, expressing like and dislike, cause and effect, greeting people, summarizing and predicting and also can be use phase of knowledge contraction such as sharing information, exploring dissonance, negotiating meaning, modifying proposed synthesis and applying new knowledge well. It was the guidance on online interactive communication in their blog's comment that must be mastered by students.

\subsection{Online Interactive Communication}

Lin (2003), Communication used technology is increasing in this era. Even communication is only technologies, but some factors will come to the communicator and technology. Here communicator is students. We know that communication in using technologies is very useful for students who want to increase their ability in communication. For the significance of these social tools is the most visible not only in terms of the amount of time they consume in human communication on a daily basis, but also in the level of scholarly research they help generate.

In using technology to increase communication skill by interaction in media online is a realization in using technology to the educational section. Education must flow to the era of this world. Education is dynamics, and technology also has benefits for students to increase their skill, especially in communication. By interaction in communication using media online, we hope that students will get some topic that interest for them so they will always have interaction in media online. Some factors that support in increasing students' communication. Many experts in the past believed that there is no single rule in communication, but somehow in the educational section it's exist. Therefore this study intended to use blog as one of the media online that can improve student ability in communication as its role.

A blog is already used in a subject in English Education Department, namely Linguistic and Semantic. The student in using Blog is a base step for them to develop their communication. Even in the Blog student only focus on the topic that presented in their topic, but students still can to practice their communication in using many new phrases that can they use to command, suggestion or critic blog their friend. Lecturer asked students to command, suggestion or critic in the blog using the command, such as must. So, communication really happens in the blog. This study found that blog can be an attractive communication when one student post a topic and another student comment after those students who posted a topic reply to the comment. The previous sentence is the plot of interactive communication in the blog. Therefore, this plot will be a guide for this study to research interactive communication by media online.

\subsection{Blog Application in ELT}

The touch of sophisticated technology information makes the learning media to be more variation, creative, and innovative, also giving a massive impact on the learning process. Aydin (2014) in the article entitled " The Use of Blogs in Learning English as a Foreign Language" found 3 impacts of using the blog in the context of ELT (English Language Teaching):

First, blogging as a language learning strategy makes significant contributions to enhancing learners' cultural knowledge and cultural awareness about the target society. More over the use of blogs enhances learners 'cultural interactions, competencies, and exchanges. Second, blogging plays an important role in developing learners' interaction and communications in the target language. Third, blogs are effective tools for developing speaking, reading and writing skills. (Aydin, 2014, p.252). The benefits based on Aydin (2014) are: First, toward the writing activity on blog or 
blogging, making it possible for the students to widen their knowledge and awareness of their culture or the new one. Second, to build the ability to interact and communicate with students by using the target language. Third, to make the blog as a facilitator to developing speaking, reading and writing ability. In accordance to that, Noytim, 2010; Guttler, 2011; Aydan, 2014 have proven the effectiveness of using the blog that can maximize the benefit of it to the teachers, lecturers, and students of English all over the world.

In the last four years, English Education Department (PBIG) Faculty of Teacher Training and Education (FKIP) Universitas Lancang Kuning has tried to apply the use of students' blog as a part of elearning system in some courses. With the help of this blog application, some lecturers and students in FBIG FKIP Unilak can post the learning materials, assignments, or information that are useful and supported their learning process. Therefore, it will be easier to access information. Students can learn anywhere, anytime, and the lecturers could upload various materials of teaching without being burdened by the time and place. (Hamuddin, 2016, p.27). In his research, Hamuddin (2017, p.19) also describes "The use of blog has given a massive impact on the learning process at PBIG FKIP Unilak, but then every new thing will have its own risk and challenge" that should be faced by the lecturers, students, and faculty together.

\subsection{Phases of Knowledge Construction}

In Gunawardena et al.'s (1997) model, knowledge contraction occurs in a series of successive (though not necessarily strictly sequential) phases that can be viewed as generally moving from lower to higher mental functions. In the model, learners begin by sharing, clarifying, and elaborating ideas (Phase 1: Sharing Information). Then, conflicts among them are explored (Phase 2: Exploring Dissonance). Next, learners reconcile conflicting ideas by negotiating their 446 A.F. Wise, M.M. Chiu Author's personal copy meanings and co-constructing new knowledge propositions (Phase 3: Negotiating Meaning). Learners may then test and revise their synthesized ideas (Phase 4: Testing and Modifying). Finally, they can state and apply their new knowledge (Phase 5: Agreeing and Applying). See Table 1 for detailed descriptions and examples of each of the phases. The drive is to achieve higher phases of KC; however, successive phases build on each other. Hence, all phases contribute to the knowledge contraction process (Gunawardena et al. 1997).

While Gunawardena et al.'s (1997) model conceptualize knowledge construction as a process which occurs through learners' interactions (via their posts), previous work has not capitalized on its capacity to examine this process by analyzing patterns of knowledge contraction. Past studies have often evaluated discussion quality by counting the posts in each knowledge contraction phase (e.g., Marra et al. 2004; Schellens et al. 2007) or by computing the discussion's average knowledge contraction phase (e.g., Schellens et al. 2005). These compiled measures treat knowledge contraction as an outcome variable where more posts in higher knowledge contraction phases indicate better learning; however, the scheme was designed as a model of the process of constructing knowledge. Importantly, two discussions can proceed quite differently, while having the same knowledge contraction phase counts (e.g., a sequence of posts with knowledge contraction phases 1212312123 vs 1111222233). By treating knowledge contraction as an aggregate outcome of individual contributions, prior studies failed to test a central underlying premise of the model: groups construct knowledge through a specific sequence of phases. In this study, we addressed this issue by analysing how the group proceeds through the phases of the knowledge contraction process.

Table 1.1 The five phases of Knowledge Construction

\begin{tabular}{|c|c|c|}
\hline No & Title & Description \\
\hline 1 & $\begin{array}{l}\text { Sharing } \\
\text { information }\end{array}$ & $\begin{array}{l}\text { Statements of observation, opinion, } \\
\text { agreement, clarification, example or } \\
\text { problem definition etc. }\end{array}$ \\
\hline 2 & $\begin{array}{l}\text { Exploring } \\
\text { dissonance }\end{array}$ & $\begin{array}{l}\text { Identification of areas of } \\
\text { disagreement; clarification of source } \\
\text { and extent of disagreement; } \\
\text { providing support for one's ideas in } \\
\text { the face of counterarguments }\end{array}$ \\
\hline 3 & $\begin{array}{l}\text { Negotiating } \\
\text { meaning / } \\
\text { constructing } \\
\text { knowledge }\end{array}$ & $\begin{array}{l}\text { Identification areas of agreement } \\
\text { across conflicting ideas; clarification } \\
\text { of meanings of terms; proposal and } \\
\text { negotiation of integrating metaphors } \\
\text { and } \\
\text { compromise statements }\end{array}$ \\
\hline 4 & $\begin{array}{l}\text { Testing / modifying } \\
\text { proposed synthesis }\end{array}$ & $\begin{array}{l}\text { Testing the proposed synthesis } \\
\text { against "received facts," cognitive } \\
\text { schema, personal experience, } \\
\text { collected data, and expert } \\
\text { testimonies. }\end{array}$ \\
\hline 5 & $\begin{array}{l}\text { Agreeing/applying } \\
\text { new knowledge }\end{array}$ & $\begin{array}{l}\text { Summarization of agreement(s); } \\
\text { application of new knowledge; } \\
\text { metacognitive statements of changes } \\
\text { in knowledge or ways of thinking. }\end{array}$ \\
\hline
\end{tabular}

\subsection{Language Function}

Discussing Language Function and blog are really interesting for this study because, in the blog, they are also using language function. According to Ludwig Wittgenstein (1976) (in Sandra A, 2016) Thompson and Elizabeth Couper-kuhlen, Language function is Characteristic of our language that the foundation which it grows consists in steady ways of living, regular ways of acting. Its Function is determined above all by action, which it accompanies. For the language itself is humans' fundamental an instrument tool to share their ideas or feeling. Refers to the 
language as an instrument tool, this statement is also supported by Sandra A. Thompson and Elizabeth Couper-kuhlen. This expert said Language is fundamental as an instrument tool. Language Function is influenced by external and internal grammar, cultural, social and psychological of human.

Language is the most important tool of communication invented by human civilization. Language helps us share our thoughts and understand others. It's hard to overestimate the importance of language for our lives. Every time we speak, we do it with a particular purpose. Sometimes we want to deliver a message or express our feelings. Language functions refer to the purposes in which we use language to communicate. We use language for a variety of formal and informal purposes, and specific grammatical structures and vocabulary are often used with each language function. In language function there is six aspects, the aspect language functions include: compare and contrast, persuasion, asking questions, expressing likes and dislikes, cause and effect, summarizing, sequencing, predicting, agreeing/disagreeing, greeting people/introductions (Susan and Carol: 2002).

When teaching about language functions, it is important that teachers explicitly teach the vocabulary and phrases associated with each language function. For example, when teaching the language function of compare/contrast, teachers may teach the following vocabulary: both, similar, also, different, in contrast, similarly, etc. During the lesson planning and preparation stage, teachers should brainstorm the vocabulary words associated with the language function that will be taught. It is important that as students become familiar with the vocabulary associated with each language function that more advanced functional vocabulary is introduced to students. All definition of Language Function in this paragraph is really important for this research. A blog is a place where language function exists, and this is the reason the important thing to understand well about language function.

\section{Method}

This qualitative study employs descriptive analysis (The research employed a qualitative descriptive method as the methodology following Creswell, J.W. Mentioned that "qualitative research is an inquiry process of understanding a social or human problem based on building a complex, holistic picture, formed with words, reporting detailed views of informants, and conducted in a natural setting". The design of this research employs descriptive research. This research design describes what exists and may help to uncover new facts or meaning. This Descriptive research focuses on gathering numerical data, then generalizing it to explain a particular phenomenon and making a systemic description. The population of the research enrolled in three morphology classes 2018/2019 academic Year, since it's using a total sampling strategy.

Moreover, this present study, collect the corpus in student blog entries, which is taken from comments or feedback from the students' blog page. This is to ensure this study of the right information and enough data to be analysed. Corpus is used by students in their interactions in their blogs. From that, this technique had been used to measure the use of the language function and phases of knowledge construction in each class by the FKIP PBIG Unilak blogs.

The follow up of the data collection was the data analysis. The starting point for analyzing the data was to categorize the text-based utterances to explore the interactive language function and phases of knowledge construction. Therefore during the process of coding and tagging, utterances that made up of a single word, a phrase, a sentence, or a paragraph tagged according to the language function they were performing such as compare and contrast, persuasion, asking questions, expressing likes and dislikes, cause and effect, summarizing, sequencing, predicting, agreeing /disagreeing, greeting people/ introductions. Furthermore, the data then re-coded and tagged in order to explore the co-construction on the gradual process of knowledge, i.e., sharing information, exploring dissonance, negotiating meaning/ constructing knowledge, testing modifying proposed synthesis, agreeing/applying new knowledge (Gunawardena, Lowe and Anderson's, 1997).

\section{Findings}

\subsection{Meaning as Use}

This research, got many answers from the samples, consists of 64 students. When took the data, it attended a subject in morphology class, and then the lecturer of this subject did the teaching-learning by using the blog. Based on This study experience and continue to the academic year 2018/2019, every student who studied in year 2018/2019 must know and use a blog in every meeting. After every student presented their subtopic about morphology in their blog, next, another student in the class had to comment in the blog, and then the students who got comment have to reply all the comment. In commenting their friends' blogs, students are able to bully, comment, suggestion and critic in the blog. Lecturer wanted to make students familiar to technology, in this technology era. In the end of this, this study was appendices all students comment in the screenshot for this analysis.

In taking the data, this study screenshot all of comments in blog which is the topic are Morphology. This study analysed one by one the comments to get the best analysis in this research. In analysing, this 
study divided the comment into an aspect that is analysed. In this research, this study use two aspects, aspect for knowledge construction and Language function. This is an analysis of students' comment in blog, in Knowledge Construction.

a) Sharing Information

"Amar you can enjoy when you explain and do not nervous, I like your performance because you use Indonesia language to make me understand about your topic *emoticon smile”

This comment showed that the information of Amar presentation is good, so this comment is share about an information about feeling of viewer to Amar presentation.

\section{b) Exploring Dissonance}

"Mr Amar I think your performance is bad and too short. How can we understand if you just show perform like that. Sorry to say, I'm not interest to listen your perform "

This comment show about an exploring a dissonance of viewer to Amar presentation.

c) Negotiating meaning/co-constructing knowledge

"Please, improve your performance, because I'm very uncomfortable and disturbed, when I see your keringat bercucuran"

In this comment showed negotiation meaning, because the commentator such as ask to presenter to do something.

d) Testing/ modifying proposed synthesis

"What mean age in name your blog? Do not say like your face that looks old from your age *emoticon oo I'm a little curious also"

In this comment, this study saw that the commentator such as give a question to presenter to answer that question.

These are analysis of Language Function in the comment blog:

e) Expressing needs and likes

"Amar, I like your post, but sorry I need more example especially in bound Morphemes ...thanks"

This comment is expressing needs and likes of commentator to presenter of morphology subject. In this types showed that needs an information and like about the topic.

f) Describing actions

"You cannot speaking with well, the words of "eeeee" "eeeee" is too much"
In this comment showed that the commentator tried describe presenter's action in the presentation.

g) Retelling/relating past events

"Lack of examples. Cannot understand if in real sentence..."

In this comment such as hide meaning that showed a retelling the presentation of presenter in giving a real sentences.

h) Making predictions

"Your blog is good sist, but it's too long for the description. How about, if add some picture in your blog, I think that can make your blog is perfect *emoticon. Thank you"

Based on this sentences, this study got that this comments such as giving a prediction to solve the problem

i) Expressing and Supporting Opinions

"Hi, Amar I think your material is complete and good and you explained yesterday was very relaxed and not nervous, keep fighting 2NE1 or BLACKPINK haha *emoticon"

This comment is a kind of comment that showed a supporting the idea or opinion about something in expressing an opinion to the blog.

In analysis of this knowledge construction comment, the This study used the indicator from a journal entitled "In support of the interaction Analysis model for evaluating discourse in a virtual learning community" this journal is uploaded in 2014. This journal is from North Central University. Based on the data this study got a result that students usually used sharing information in knowledge construction types.

There are 53 comments that used sharing information knowledge construction. This number is dominant in this knowledge construction. Then in the second position of dominant is Testing/ modifying proposed synthesis with total 8 comments, the next position after that is Exploring Dissonance and the less types knowledge construction which is use of commentator is Negotiating meaning/ co-constructing knowledge with total only 1 comment for this.

Then, this study start to analysis the comment in Language function. For analysis the language function of the comments, it use Susana Dutro and Carol Moran's entitled Rethinking English Language Instruction: An Architectural Approach, 2002. This journal showed about language function with clear and brief. In this journal, this study got that language function also use for speaking not only writing, based on these journal This study analysis all the comments to identify the comment to categories language function. 
This study got that in the dominant in the language function is expressing and supporting opinion, which is 29 comments. Then the next is describing actions which is 20 comments. Then students usually write something in expressing needs and likes to their friends Not only that, students also shown that they are usually use sentences like making predictions is four comments. The next is three comments use retelling /relating past events. The last is asking informational questions, there is no students asking informational questions.

For more detailed, showed in here the table of it. The table discussed clearly with an analysis. Analysis is a way which is this study use in this research to get identification in this research. Analysis can help this study to identify the knowledge construction and all this study need. This research consists of analysed the dominant response or comment in blog. These are tables of knowledge construction and language function.

Table 3.1 Knowledge Contraction of Students Comments

\begin{tabular}{ccccccc}
\hline \multirow{2}{*}{ No } & \begin{tabular}{c} 
User Blog \\
Class \\
\cline { 3 - 7 }
\end{tabular} & \multicolumn{5}{c}{ Knowledge Contraction } \\
\cline { 3 - 7 } & Class A & 29 & 2 & 1 & 4 & - \\
\hline 1 & SI & ED & NM & T & ANK \\
2 & Class B & 13 & - & - & - & - \\
3 & Class C & 11 & - & - & - & - \\
& Total & 53 & 2 & 1 & 4 & 0
\end{tabular}

Notes:

$\mathrm{KC}$ : Knowledge contraction

SI : Sharing information

ED : Exploring dissonance

NM : Negotiating meaning or co-constructing knowledge

$\mathrm{T} \quad$ : Testing/modifying proposed synthesis

ANK : Agreeing/applying new knowledge

The indicators of Knowledge Construction they are divided into five categories, the first categories is Sharing \& Comparing of opinion, consist of five indicators, they are Statement of observation or opinion, Statement of agreement, Corroborating examples, Asking and answering question to classify details of statements, Definition, description or identification of a problem. This indicator which is used this study to categorize all the comment. The second categories is The discovery and exploration of dissonance or inconsistency among ideas, concepts or statement, consist of three indicators, they are Identifying and stating areas of disagreement, Asking and answering questions to clarify the source and extent of disagreement and Restarting the participant's position and possibly advancing arguments or considerations in its support by references to the participant's experience, literature, formal data collected or proposal of relevant metaphor or analogy to illustrate point of view.

The third categories of knowledge Construction, is Negotiation \& Co-Construction, consist of five indicators Negotiation of the relative weight to be assigned to arguments, Identification of areas of agreement or overlap among conflicting concepts, Proposal and negotiation of new statements embodying compromise, co-construction, Proposals integrating or accommodating metaphors or analogies.

The Fourth Testing/modification proposed synthesis or co-construction, consist of five indicators, they are testing the proposed synthesis against 'received fact' as shared by the participants and/or their culture, Testing against existing cognitive schema, Testing against personal experience, Testing against formal data collected, testing against contradictory testimony in the literature. The last category is Agreement statement (application of new construction meaning), the indicators of these categories such as Applications of new knowledge, Metacognitive statements by the participants illustrating their (cognitive schema) has changed as a result of the interaction.

Table 3.2 Language Function of Students Comments

\begin{tabular}{cccccccc}
\hline & Users & \multicolumn{5}{c}{ Language Function } \\
\cline { 3 - 8 } No & $\begin{array}{c}\text { Blog } \\
\text { Class } \\
\text { (UBC) }\end{array}$ & ENL & DA & RPE & MP & AIQ & ES \\
\hline 1 & Class A & 5 & 19 & - & 1 & - & 12 \\
2 & Class B & 2 & 1 & - & - & - & 10 \\
3 & Class C & 1 & - & 3 & 3 & - & 7 \\
& Total & 8 & 20 & 3 & 4 & 0 & 29 \\
\hline
\end{tabular}

Notes:

LF : Language Function

ENL : Expressing needs and likes

DA : Describing actions

RPE : Retelling/relating past events

MP : Making predictions

AIQ : Asking Informational Questions

ESO : Expressing and Supporting Opinions 
The next aspect of language function, the first category is Expressing needs and likes, the indicator is consist of three indicators, they are Indirect/ direct object, Subject/ verb agreement, Pronouns. The second category is Describing people, places and things, the indicator of these categories, they are Nouns, Pronouns, and Adjectives. The next category is Describing the action in describing action consist of two indicators, they are Present progressive and Adverbs. The next category is Retelling/relating past events, the indicators of this category, they are Past tense verbs and Perfect aspect (present and past). The next category is making predictions, the indicators they are Verbs: future tense, conditional mode. The next category is Asking Informational Questions, the indicators they are Verbs and verb phrases in question. The last category is Expressing and Supporting Opinions, the indicators they are Sentence Structure and Modals (will, can, may, shall).

\section{Discussion}

Discussion is the main part of this research. Here, this study provides the result of her analysis in the blog comment with topic morphology. This study only provides the data which contain finding type of knowledge construction and language function. The detail explanations are as follows:

As classified previously, this research was conducted among English students in morphology class of Faculty Education and Teacher Training Universitas Lancang Kuning Pekanbaru, in the knowledge construction, This study got that sharing information is dominant to use in students blog comments and then in language function the majority result in the language function is expressing and supporting opinion in students blog comments.

Back to the related finding in the previous research, it was shown that many previous perspectives share their result to the world in their own mind. The first related finding is interaction in the Apple Support Communities, daily interaction between a customer and the operator service of Apple Communities, in this community they only talk about something without enjoy because of the busy to judge each other and bore. The second related finding, entitled Understanding Students' Online Interaction: Analysis of Discussion Board Postings in 2011. The purpose of this research was to report on the findings of a study examining students' online interaction patterns. Various data analysis methods such as descriptive and regression analyses were utilized to examine students' evolving interaction pattern and different interaction patterns among students in the same class. The result of this research is students demonstrated considerable variability in posting behaviour, ranging from 7 to 169 , with an average of 65.1 posts per person $(\mathrm{SD}=33.6$, Median =64). As with Level 1 codes, but not Level 2, statistically significant differences were found across students, supporting the interpreting of student heterogeneity in the rate of posting.

The third related finding is entitled Use of online interactive tools in an open distance learning context: Health Studies Students' Perspectives, from Department of Health Studies, University of South Africa, South Africa in 2017. The purpose of this study was to determine how the discussion as an online interactive tool be used in an ODL (Open Distance Learning) institution to enhances student-to students and students-to-lecturer online interaction. This study used quantitative and descriptive in nature. In taking the data, this research consists of 410 participants, but only 87 students responded to the questionnaire and it was showed by the diagram. So, in this method, no sampling was set in this study.

The fourth related finding is entitled The Importance of Interaction for Academic Success in Online Course with Hearing, Deaf and Hard-of Hearing Students, from Rochester Institute of Technology, University, United State. This paper separated three studies within a program of research designed to better understand the factors contributing to the academic achievement of students' online course and the interaction to online learning. In the final study, both datasets were used to determine the academic achievement of students in an online course based upon the amount of interaction that had actually occurred. The fifth related findings is entitled Uses of Social Media on Student's Communication and Self Concepts among TATIUC Students, from TATI

University College in 2016. In this study was carried out to examine how the TATI University College (TATIUC), this study wants to see the relationship between their communications and selfconcepts. Participants of this study are 2000 undergraduate students from TATIUC. The result shows that $90.5 \%$ of respondents indicate that they use some form of social media.

All of these related findings are only focus on the interest of students in the discussions online forum, these all previous research did not analysis the comments with species such as Language Function and knowledge construction. The analysis is an important thing in English teaching which is using a blog as media online. In this research, this study analysed students' comments. This research is more important than previous research. Previous research only discusses students' interest of using media online in teaching, but in this research, this study comes with a new better result to teaching-learning in media online with specific analysis about knowledge construction and language function. 


\section{Conclusion}

This study analysis set its conclusions in two aspects i.e., Knowledge Construction and Language Function. Share Information seems the most dominant type can be found in Knowledge Construction and In Language Function students the dominant type is Expressing and Supporting Opinions.

\section{Acknowledgement}

The writers give their gratitude to anonymous reviewers and colleague who assisted immensely in the production of this research article, especially for their feedback and critic.

\section{References}

Aydan, L.S. (2014). Student and Teacher Perceptions of Benefits and Challenges of Using Blogs in English in Foreign Language Reading Classes. (Master's thesis). Ankara: Middle East Technical University Press.

Aydin, S. (2014). The Use of blogs in learning English as a foreign language. Online Submission, 4(1), 244-259.

Boas, I. V. (2011). Process writing and the Internet: Blogs and Ning networks in the classroom. In English Teaching Forum (Vol. 49, No. 2, pp. 26-33). US Department of State. Bureau of Educational and Cultural Affairs, Office of English Language Programs, SA-5, 2200 C Street NW 4th Floor, Washington, DC 20037.

Creswell, J.W. (1994) Research Design: Qualitative and Quantitative Approaches. Retrieved from Creswell, J. W. (2002). Educational research: Planning, conducting, and evaluating quantitative (pp. 146-166). Upper Saddle River, NJ: Prentice-Hall.

Dutro, S., \& Moran, C. (2003). Rethinking English language instruction: An architectural approach. English learners: Reaching the highest level of English literacy, 227, 258.

Gritsenko, V. (2015). Interaction Forum and Group Communication: a Case Study of a support community. Journal of Social and Behavioral Sciences., 236 (2016). 14-21.

Gunawardena, C.N., Lowe, C. A., \& Anderson, T. (1997) Analysis of Global Online debate and the development of an interaction analysis model of examining the social construction of knowledge in computer conferencing. Journal of Educational Computing Research, 17(4), 397431.
Guttler, F. ( 2011) The use of blogs in EFL teaching. The Journal of Brazilian English Language Teaching. 2(1): 59-68.

Hamuddin, B. (2016). Improving EFL Students Through Blog: Did Blogging Activity Influence.

Huang, H. C. (2015). From web-based readers to voice bloggers: EFL learners' perspectives. Computer Assisted Language Learning, 28(2), 145-170.

Lin, Carolyn A (2003). An Interactive Communication Technology Adoption Model. Communication Theory 13(4):345 - 365 .

Lin, M. H. (2015). Learner-Centered Blogging: A Preliminary Investigation of EFL Student Writers' Experience. Educational technology \& society, 18(4), 446-458.

Lin, M. H., Groom, N., \& Lin, C. Y. (2013). Blogassisted learning in the ESL writing classroom: A phenomenological analysis. Journal of Educational Technology \& Society, 16(3), 130139.

Long, L.Gary, Marchetti, Carol \&Fasse R.(2011). The Importance of Interaction for Academic Success in Online Course with Hearing, Deaf and Hardof-Hearing Students. Research Article of The International Review of Research in Open Distance Learning (IRRODL). Vol.12, No.6.119

Lu Ludwig Wittgenstein (1976). Language. Function.in Sandra A, Thompson and Elizabeth Couper-kuhlen.

Maboe, K.A. (2017). Use of Online Interactive Tools In An Open Distance Learning Context: Health Studies Students' Perspectives. Journal of Science Direct. 2016.1-7.

Miyazoe, T., \& Anderson, T. (2010). Learning outcomes and students' perceptions of online writing: Simultaneous implementation of a forum, blog, and wiki in an EFL blended learning setting. System, 38(2), 185-199.

Noytim, U. (2010). Weblogs enhancing EFL students' English language learning. Procedia-Social and Behavioral Sciences, 2(2), 1127-1132.

Othman, Wan Roslina W, NgahHaslinda N. \&Fariha Z. (2016). The Uses of Social Media on Student's Communication and Self Concepts among TATIUC Students. Journal of Science and Technology. 9(17. 1-9.

Shanthi, A., Wah, L. K., Lajium, D., \& Thayalan, X. (2015). Language Function and Knowledge Construction in Online Discussion Board Forums. Frontiers of Language Teaching. Vol. 6. 
Song, Liyan \& McNary W. Scot. (2011). Understanding Students' Online Interaction Analysis of Discussion Board Postings. Journal of Interactive Online Learning. 10 (2011). 1-14.

Students' English Skill?. ELT-Lectura Journal. 3(2): 18. Hamuddin, B. (2017). Identification of Common Problems in Blogging Based Class at PBIG FKIP Unilak. ELT-Lectura, 4(1): 35-42.

Sun, Y. C., \& Chang, Y. J. (2012). Blogging to learn: Becoming EFL academic writers through collaborative dialogues. Language Learning \& Technology, 16(1), 43-61.

Suryana. (2010). Metode Penelitian Model Praktis Penelitian Kuantitatif dan Kualitatif. Bandung: UPI.

Susana Dutro and CatrolMorans. 2002. Language Function.Rethink English Language Instruction: An Approach.

Thayalan, X. (2011). Social Networking Strategies and Tactics Among Tertiary Students Bloggers. Unpublished Ph. D Thesis. Kuala Lumpur: University Malaya.

Wang, M., Fix, R., \& Bock, L. (2004). Blogs: Useful tool or vain indulgence. In E-Learn 2005: World Conference on E-Learning, Oct (pp. 24-28).

Zhang, W. (2010). Blogging for doing English digital: Student evaluations. Computers and Composition, 27(4), 266-283. 